\title{
Hypertrophic and noncompacted cardiomyopathy of left ventricle: different manifestations of the same disease
}

\author{
Vesna Pehar \\ Pejčinovič*, \\ Viktor Peršić, \\ Marko Boban, \\ Marijana Rakić, \\ Helena Antić Kauzlarić, \\ Vladimir Peša
}

Clinic for Treatment,

Rehabilitation and Prevention of Cardiovascular Diseases,

Thalassoterapia Opatija,

Opatija, Croatia
KEYWORDS: hypertrophic cardiomyopathy, left ventricular noncompaction, overlapping

CITATION: Cardiol Croat. 2017;12(4):135. | https://doi.org/10.15836/ccar2017.135

*ADDRESS FOR CORRESPONDENCE: Vesna Pehar Pejčinović, Thalassotherapia Opatija - Klinika za liječenje, rehabilitaciju i prevenciju bolesti srca i krvnih žila, Ul. Maršala Tita 188, HR-51410 Opatija, Croatia.

Phone: +385-51-202-720 / E-mail: pehar.vesna@gmail.com

ORCID: Vesna Pehar Pejčinović, http://orcid.org/0000-0002-8921-7999 • Viktor Peršić, http://orcid.org/0000-0003-4473-5431 Marko Boban, http://orcid.org/0000-0002-6129-575X • Helena Antić Kauzlarić, http://orcid.org/0000-0002-2563-7441 IIIIIIIIIIIIIIIIIIIIIIIIIIIIIIIIIIIIIIIIIIIIIIIIIIIIIIIIIIIIIIIIIIIIIIIIIIIIIIIIIIIIIIIIIIIIIIIIIIIIIIIIIIIIIIIIIII Hypertrophic cardiomyopathy (HCM) and left ventricular noncompaction (LVNC) are both genetically determined and familial diseases. Hypertrophic cardiomyopathy (HCM) is defined as hypertrophy of the myocardium more than $1.5 \mathrm{~cm}$, without another identifiable cause, such as long-standing hypertension, amyloidosis, aortic stenosis, glycogen storage disease. Many of the mutations associated with HCM involve the cardiac sarcomeric proteins and include actin, myosin, or troponin component of the sarcomere and it is most frequently transmitted as an autosomal dominant trait. Left ventricular noncompaction is a rare congenital cardiomyopathy which is characterized by the presence of a thin, compacted epicardial layer and a non-compacted thicker endocardial layer of myocardium, with prominent trabeculation and deep recesses communicating with the cavity of the left ventricle. The cause of the disorder has been identified as mutations in genes associated with the mitochondrial function, like G4.5 which encodes the protein tafazzin, genes related with the cytoskeleton, like those of alpha-dystrobrevin or dystrophin, genes that code proteins of the Z line of the sarcomere, like LDB3, which codes the protein Cypher/ZASP, genes of the internal nuclear membrane proteins (LMNA which encodes lamin A/C) and even genes that code sarcomeric proteins like cardiac alpha-actin and the beta-myosin heavy chain and cardiac troponin T. The clinical picture of both diseases, HCM and LVNC, varies from mild forms until severe forms with heart failure and complex ventricular arrhythmias. LVNC and HCM may appear as overlapping entities. Cases of patients sharing both the LVNC and HCM phenotypes have been already published, and it is speculated that mutations in sarcomere protein genes known to cause hypertrophic cardiomyopathy and dilated cardiomyopathy may be associated with left ventricular noncompaction..$^{1-5}$ In our case report, we are presenting patient with clear overlapping pheenotyp for LVNC and HCM, using the imaging method cardiac MRI.

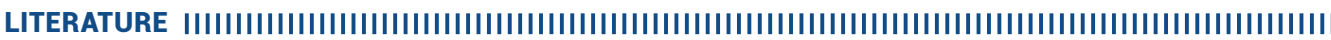

1. Murphy RT, Thaman R, Blanes JG, Ward D, Sevdalis E, Papra E, et al. Natural history and familial characteristics of isolated left ventricular noncompaction. Eur Heart J. 2005 Jan;26(2):187-92. https://doi.org/10.1093/eurheartj/ehi025

March 11, 2017

ACCEPTED:

April 6, 2017

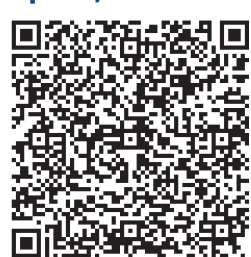

2. Monserrat L, Hermida-Prieto M, Fernandez X, Rodríguez I, Dumont C, Cazón L, et al. Mutation in the alpha-cardiac actin gene associated with apical hypertrophic cardiomyopathy, left ventricular non-compaction, and septal defects. Eur Heart J. 2007 Aug;28(16):1953-61. https://doi.org/10.1093/eurheartj/ehm239

3. Pantazis AA, Kohli SK, Elliott PM. Images in cardiology. Hypertrophic cardiomyopathy and left ventricular hypertrabeculation: evidence for an overlapping phenotype. Heart. 2006 Mar;92(3):349. https://doi.org/10.1136/hrt.2005.070110

4. Biagini E, Ragni L, Ferlito M, Pasquale F, Lofiego C, Leone 0 , et al. Different types of cardiomyopathy associated with isolated ventricular noncompaction. Am J Cardiol. 2006 Sep 15;98(6):821-4. https://doi.org/10.1016/j.amjcard.2006.04.021

5. Hoedemaekers YM, Caliskan K, Majoor-Krakauer D, van de Laar I, Michels M, Witsenburg M, et al. Cardiac beta-myosin heavy chain defects in two families with non-compaction cardiomyopathy: linking non-compaction to hypertrophic, restrictive, and dilated cardiomyopathies. Eur Heart J. 2007 Nov:28(22):2732-7. https://doi.org/10.1093/eurheartj/ehm429 